\title{
CITRIC ACID-BASED DEEP EUTECTIC SOLVENTS: PHYSICAL PROPERTIES AND THEIR USE AS COSOLVENTS IN SULPHURIC ACID-CATALYSED ETHANOLYSIS OF OLEIC ACID
}

Dragan Z. Troter ${ }^{1^{*}}$, Milica Z. Zlatković1 ${ }^{1}$ Dušica R. Đokić-Stojanović2 ${ }^{2}$ Sandra S. Konstantinović ${ }^{1}$, Zoran B. Todorović ${ }^{1}$

${ }^{1}$ Faculty of Technology, University of Niš, Leskovac, Serbia

2 Zdravlje Actavis, Leskovac, Serbia

Deep eutectic solvents (DESs) are noted to be green ionic liquid (IL) analogues, and their many favourable properties made them interesting for the scientific community. In this study, two novel DESs of citric acid with the monosaccharides D-glucose or D-fructose (1:1 molar ratio) were prepared and characterized. At the atmospheric pressure, the density, the dynamic viscosity, and the electrical conductivity of these eutectic solvents were measured and analysed as the function of temperature in the practical temperature range of 293.15-363.15 K. Arrhenius theory was employed for understanding the transport phenomena in these DESs. By using the experimental data, some important properties were calculated such as molecular volume, lattice energy, heat capacity, molar Gibbs energy, enthalpy and entropy of activation of viscous flow for the synthesized DESs. The fractional Walden rule was employed to establish the relationship between molar conductivity and viscosity, which proved an excellent linear behaviour.

Finally, these DESs were tested as cosolvents in oleic acid (OA) ethanolysis. The investigated DESs possess many desirable properties, such as low vapour pressure, inflammability, biodegradability, and can be obtained from available renewable resources. These DESs showed to have the potential to be utilized for several industrial applications, like processing and separation of food constituents, pharmaceutical applications, and mediums for chemical reactions.
(ORIGINAL SCIENTIFIC PAPER) UDC 66.061.18:547.477:577.114
Keywords: deep eutectic solvent, citric acid, glucose, fructose, physical properties, ethanolysis

\section{Introduction}

Ionic liquids (ILs) present organic salts that consist of ions and are liquid at temperatures below $100{ }^{\circ} \mathrm{C}$ [1]. These nonaqueous solvents have favourable physical and chemical properties. Some of them have a wide liquid range, high chemical and thermal stabilities, negligible vapour pressure, low flammability, and high ionic and thermal conductivity. Also, they are successful in dissolving a wide range of organic and inorganic compounds [1]. Cations in ILs are organic (nitrogen- or phosphorouscontaining), while anions can be organic or inorganic [2]. By possessing minimal toxicity to the environment, some ILs are considered "green". Some of the processes in which ILs proved to be successful include catalysis [3], electrochemistry [4-5], separation [6] and inorganic nanomaterials [7-8]. Because of their complex synthesis and expensive starting reactants, these days ILs are being replaced with deep eutectic ILs or deep eutectic solvents (DESs). Some features of these solvents give them an advantage over ILs because DESs are easier to prepare with high purity at low cost. DESs are made by mixing organic halide salts with a complexing organic agent (usually a $\mathrm{H}$-bond donor) in proper ratios, thus forming eutectic mixtures which are liquid at temperatures below $100{ }^{\circ} \mathrm{C}$ [9-12]. The complexing agent interacts with anion and increases its effective size. The final result is decreasing the interaction between anion and cation, so that freezing point depression of the mixture occurs. DESs have been applied in organic reactions [13-15], extractions [16], electrochemistry [17-19], and enzyme reactions [20]. In this paper two novel DESs have been synthesized by combining citric acid with monosaccharides D-glucose or D-fructose in 1:1 molar ratio. If we compare these DESs to ILs, they are cheaper and easier to make, less toxic and biodegradable. In order to find their future applications, their physical properties (density, viscosity and electrical conductivity) are very important. To our best knowledge this may be the first study on the density and transport properties (viscosity and electrical conductivity) of the mixtures of citric acid with the monosaccharides D-glucose or D-fructose, respectively, in the composition 1:1 molar ratio. Their densities, viscosities and electrical conductivities were

\footnotetext{
*Author address: Dragan Z. Troter, Faculty of Technology, University of Niš,

Bulevar oslobođenja 124, 16000 Leskovac, Serbia

E-mail: drtroter@gmail.com

The manuscript received: February, 17, 2016.

Paper accepted: March, 21, 2016.
} 
determined at several temperatures. Correlations for the temperature dependences of the measured properties are done and discussed in the terms of Arrhenius theory.

The fractional Walden rule was used to study the relationship between the molar conductivity and the viscosity. At last, the possibilities of using these DESs as cosolvents in OA ethanolysis were reflected.

\section{Experimental}

\section{Materials}

Citric acid monohydrate $(99.5 \%)$ was purchased from Zorka Šabac, Serbia. D-glucose (99.0\%) and D-fructose (99.0\%) were obtained from MosLab Belgrade, Serbia. Oleic acid and concentrated sulphuric acid (reagent grade $98.0 \%$ ) were provided from Sigma-Aldrich. Absolute ethanol (99.5\%) was purchased from Lachema (Czech Republic), Also, the following solvents were used: n-hexane (99.0\%, Promochem, Germany), n-hexane and 2-propanol (HPLC grade, JT Baker). The standard for ethyl oleate was purchased from Sigma Co. All reagents were used without further purification.

\section{Preparation of DESs}

To prepare the DESs, citric acid was mixed with
D-glucose or D-fructose at 1:1 molar ratio in a roundbottomed flask. The flask was then placed on a rotary evaporator, at $348.15 \mathrm{~K}$ until a homogeneous liquid was formed. DESs were stored in well-closed, glass bottles in a desiccator containing $\mathrm{CaCl}_{2}$. Figure 1 represents DESs preparation process, and visible properties of the prepared DESs at room temperature are listed in Table 1.
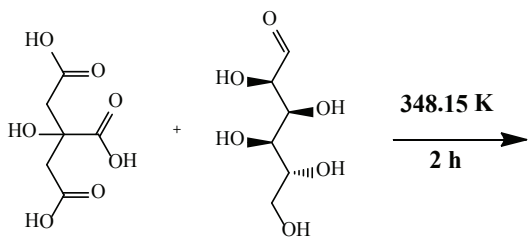

Citric acid (1 mole) Glucose (1 mole)

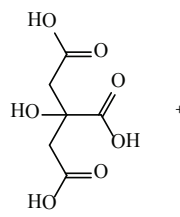

Citric acid (1 mole)

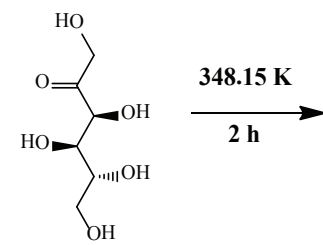

Fructose (1 mole)

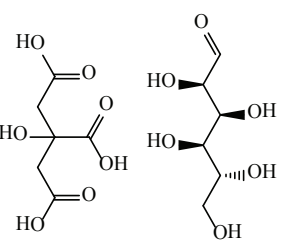

Citric acid:glucose $(1: 1)$

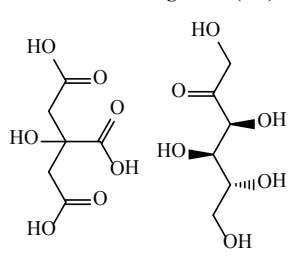

Citric acid:fructose (1:1)
Figure 1. Preparation of deep eutectic solvents

Table 1. Prepared DESs and their visible properties at room temperature

\begin{tabular}{lccc}
\hline DES & Composition & $\begin{array}{c}\text { Citric acid: } \\
\text { monosaccharide } \\
\text { molar ratio } \\
\text { (mol/mol) }\end{array}$ & $\begin{array}{c}\text { Visible properties of DES at room } \\
\text { temperature }\end{array}$ \\
\hline DES1 & Citric acid:D-glucose & $1: 1$ & Liquid, viscous, homogeneous, light yellow \\
DES2 & Citric acid:D-fructose & $1: 1$ & Liquid, viscous, homogeneous, dark brown \\
\hline
\end{tabular}

Measurements of the physical properties of DESs

Physical properties (density, dynamic viscosity, and electrical conductivity were measured for synthesized DESs within 293.15-363.15 $\mathrm{K}$ temperature range. All measurements were performed three times at each temperature, in the air at ambient pressure, and their mean values were used for comparison. The dependences of the selected physical property with temperature were established for each system and the corresponding "best" equations for the same temperature range were conducted. The temperature dependent equations were systematized for each property. Karl-Fischer moisture titrator (Metrohm 73KF coulometer) was used to determine the water content of the dried DESs, and the values were less than 300 ppm.

Measurements of the densities of DESs

At atmospheric pressure, the densities $(\rho)$ of all samples of DESs were measured with a DMA 4500 Anton Paar densitometer. The sample thermostatting was controlled to $\pm 0.1 \mathrm{~K}$.
Measurements of the dynamic viscosities of DESs The dynamic viscosities $(\eta)$ of the DESs were determined by rotational viscosimeter (Visco Basic Plus v. 0.8, Fungilab S.A., Barcelona, Spain). This viscometer operates by the principle of rotation of a stainless steel spindle, and when the spindle is submerged into the DES, the viscometer measures the resistance (flow viscosity) of the test substance against a pre-set speed. Based on the speed and the characteristics of the spindle, a direct reading of the viscosity in $\mathrm{mPa} \cdot \mathrm{s}$ is provided.

Measurements of the electrical conductivities of DESs

The electrical conductivity $(\mathrm{K})$ measurements were carried out by ProLine Conductivity meter B250, provided with a conductivity cell. DES was placed into a glass tube (introduced in a thermostated bath) with a ground joint and the measuring cell was sealed in order to prevent moisture diffusion. The readings were taken after 20 minutes for each temperature in order to provide good temperature equilibration between the water bath and the sample. 
Oleic acid ethanolysis

Figure 2 shows the reaction of $\mathrm{OA}$ ethanolysis and the reaction conditions of the OA ethanolysis applied are provided in Table 2. The apparatus for the reaction consisted of a $250 \mathrm{~mL}$ two-neck round-bottomed flask, placed in a glass chamber, equipped with a magnetic stirrer and a condenser. Water was circulated through the chamber from a thermostated bath. In the first series of experiments, where the effect of DESs was studied, the predetermined amounts of selected DES $(4.60 \mathrm{~g})$ and ethanol $(14.38 \mathrm{~g})$ were added into the flask. Sulfuric acid $(0.23 \mathrm{~g})$ was added to the mixture drop by drop. Oleic acid $(22.98 \mathrm{~g})$ was preheated in a glass beaker and then added into the flask. The mixture in the flask was stirred magnetically at $500 \mathrm{rpm}$ for $6 \mathrm{~h}$ at $70^{\circ} \mathrm{C}$. In the second series of experiments, DES was not added, and in the third series only DESs were used, without sulfuric acid. During the reaction, at various time intervals, the samples were taken from the reaction mixture $\left(1 \mathrm{~cm}^{3}\right)$. After the reaction, the reaction mixture was poured into a conical shaped separatory funnel and allowed to settle. All experiments were run in duplicate. The samples were centrifuged for $15 \mathrm{~min}$ at $3500 \mathrm{~min}^{-1}$. The upper layer consists of ethyl oleate and oleic acid, and the bottom layer is a mixture of sulfuric acid, water and selected DES. The quantitative composition of the upper layer (dilution 1:200 in a mixture of 2-propanol/n-hexane; 5:4 v/v) was determined by liquid chromatography (HPLC).
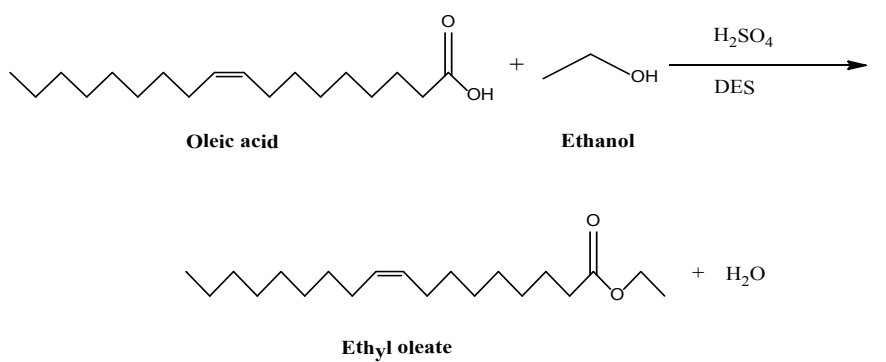

Figure 2. The simplified form of oleic acid (OA) ethanolysis

Table 2. Oleic acid ethanolysis reaction conditions

\begin{tabular}{cc}
\hline Ethanol to oleic acid ratio (mol/mol) & 3.84 \\
Sulfuric acid amount $(\mathrm{g} / 100 \mathrm{~g}$ of oil) & 1.00 \\
Amount of DES (when used) (g/100 g of oil) & 20.00 \\
Temperature $(\mathrm{K})$ & $343.15 \pm 0.1$ \\
Pressure $(\mathrm{kPa})$ & 101.30 \\
Agitation speed $(\mathrm{rpm})$ & 500.00
\end{tabular}

\section{Analytical methods}

The samples $(1 \mathrm{~mL})$ were removed from the reaction mixture during the progress of the ethanolysis reaction, cooled in an ice bath, and centrifuged (3500 rpm, 10 min). The upper layer (named ester fraction) was withdrawn, dissolved in 2-propanol/n-hexane $(5: 4 \mathrm{v} / \mathrm{v})$ in an appropriate ratio, and filtered through a $0.45 \mu \mathrm{m}$ Millipore filter. The resulting filtrate was used for a high performance liquid chromatography (HPLC) analysis, which was described in details by Stamenković et al. [21]. The conversion degree of $\mathrm{OA}(\mathrm{XA})$ was calculated from the content of OA (in \%) in the ester/oil fraction of the reaction mixture, by the following equation (1):

$X_{A}=\frac{\left(100-O_{\text {final }}\right)}{100}$.

where $O A_{\text {final }}$ is the percentage of $O A$ in the ester/oil fraction.

\section{Results And Discussions}

The effect of temperature on the physical properties of two citric acid-based deep eutectic solvents

The effect of temperature on the density of two citric acid-based deep eutectic solvents

Density represents a very important property of chemical materials. In order to obtain the data needed for a technological design, the knowledge of the temperature effect on density is very significant for engineers. Also, the thermal expansion coefficient or compressibility coefficients obtained from density can provide a liquid structure and interactions data. If the temperature of the system rises, the molecules are moving at higher speeds, so the molar volume of the solution increases. The result of this is density reduction.

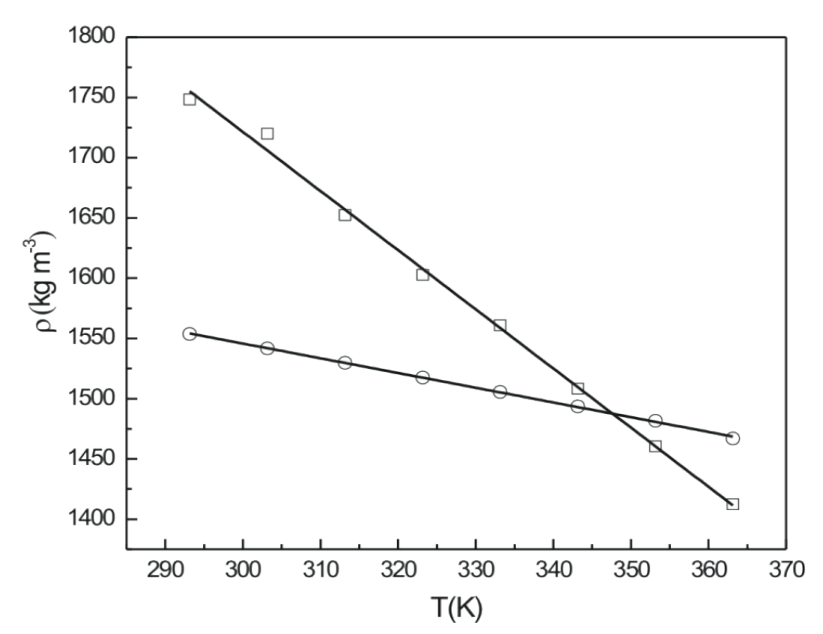

Figure 3. Temperature dependence of the density of the studied eutectic mixtures: citric acid:glucose - $\square$ and citric acid:fructose - o.

Deep eutectic mixtures densities are related to those of the solvents, as expected. Figure 3 shows the temperature dependence of the density of the studied eutectic mixtures. For almost all pure substances and mixtures, the density $(\rho)$ decreases with temperature $(T, K)$. The correlation with temperature can be expressed by a linear equation (2): 
$\rho=a+b \cdot T$

where the parameters "a" (the density at $0 \mathrm{~K} \mathrm{in} \mathrm{kg} \cdot \mathrm{m}^{-3}$ ) and "b" (the coefficient of volume expansion in $\mathrm{kg} \cdot \mathrm{m}^{-3} \cdot \mathrm{K}^{-1}$ ) were determined from the intercept and slope, respectively, of the corresponding straight lines obtained from the evolution of density with temperature. Table 3 shows the density equation parameters, standard deviations $(\sigma)$ and correlation factors (Adj. $\mathrm{R}^{2}$ ) for the investigated temperature ranges for DESs. It can be noticed that the citric acid:glucose eutectic mixture has higher density than citric acid:fructose eutectic mixture at the temperature range of 293.15-343.15 K, but the density of citric acid:glucose DES declines rapidly after $353.15 \mathrm{~K}$.

Table 3. Constants of the density equation with standard deviations $(\sigma)$, correlation factors

(Adj. R2) and temperature ranges for (1:1 M) citric acid:glucose and citric acid:fructose DESs

\begin{tabular}{|c|c|c|c|c|c|c|}
\hline \multirow[t]{2}{*}{ DES } & \multirow{2}{*}{$\begin{array}{c}\text { Temp.range } \\
\mathrm{T}(\mathrm{K})\end{array}$} & \multicolumn{4}{|c|}{ Coefficients of Eq. (2) } & \multirow[t]{2}{*}{ Adj. $R^{2}$} \\
\hline & & $a\left(\mathbf{k g} \cdot \mathbf{m}^{-3}\right)$ & $\sigma[\mathrm{a}]$ & $\mathrm{b}\left(\mathbf{k g} \cdot \mathbf{m}^{-3} \cdot \mathrm{K}^{-1}\right)$ & $\sigma[\mathrm{b}]$ & \\
\hline DES1 & 293.15-363.15 & 3194.30 & 6.4735 & -4.9095 & 0.0213 & 0.9966 \\
\hline DES2 & 293.15-363.15 & 1912.50 & 0.7736 & -1.2223 & 0.0022 & 0.9992 \\
\hline
\end{tabular}

For all systems, a very good linear correlation and behaviour was observed between density and temperature, like described for pure ionic liquids [22-24]. The density values for these DESs decline from 1748.38 to $1412.38 \mathrm{~kg} \cdot \mathrm{m}^{-3}$ (for citric acid:glucose) and from 1553.68 to $1467.00 \mathrm{~kg} \cdot \mathrm{m}^{-3}$ (for citric acid:fructose) for the temperature range of $293.15-363.15 \mathrm{~K}$.

Hayyan et al. [25] studied choline chloride (2-hydroxyethyl-trimethylammonium)-based DESs with D-glucose in different molar ratios $(1: 1 ; 1.5: 1 ; 2: 1 ; 2.5: 1 ; 1: 1.5 ; 1: 2$; $1: 2.5)$ and concluded that these DESs at different ratios were colourless even after heating at high temperature $(358.15 \mathrm{~K})$, which indicated that caramelization reactions did not occur at this temperature. All densities of $\mathrm{ChCl}$ D-glucose DESs were above $1200.00 \mathrm{~kg} \cdot \mathrm{m}^{-3}$, and these values were between the room temperature densities of pure $\mathrm{ChCl}\left(1185.60 \mathrm{~kg} \cdot \mathrm{m}^{-3}\right)$ and that of pure D-glucose $\left(1534.50 \mathrm{~kg} \cdot \mathrm{m}^{-3}\right)$. ChCl-D-glucose DES (molar ratio $1: 1$ ) had the density of $1297.80 \mathrm{~kg} \cdot \mathrm{m}^{-3}$ at room temperature and $1265.90 \mathrm{~kg} \cdot \mathrm{m}^{-3}$ at $358.15 \mathrm{~K}$, but ChCl-D-glucose DES (molar ratio 2:1) had the density of $1211.50 \mathrm{~kg} \cdot \mathrm{m}^{-3}$ at $358.15 \mathrm{~K}$. Compared to the reported physical properties of phosphonium-based DES by Kareem et al. [26] it was noted that $\mathrm{ChCl}$-D-glucose DES (molar ratio 1:1) had similar values to the DES constituted from [methyltriphenylphosphonium bromide:glycerol] at the molar ratio of 1:1.75. ChCl-D-glucose DESs with molar ratios of 1.5:1; 2:1; and 2.5:1 had the densities close to the DES made from [methyltriphenylphosphonium bromide:glycerol] at the molar ratio of 1:4. ILs such as 1-hexyl-1-methyl-pyrrolidinium bis (trifluoromethylsulfonyl) imide had higher density $\left(1340.00 \mathrm{~kg} \cdot \mathrm{m}^{-3}\right.$ at $\left.293.15 \mathrm{~K}\right)$ than $\mathrm{ChCl}-\mathrm{D}-\mathrm{glu}-$ cose DES (molar ratio 1:1) [27]. ChCl-D-glucose DESs in molar ratios $1.5: 1 ; 2: 1 ; 2.5: 1$ have similar densities as some imidazolium and pyrrolidinium based ILs, such as 1-ethyl-3-methylimidazolium methylsulfate and 1-butyl1-methylpyrrolidinium trifluoromethanesulfonate, which have the density values of 1280.00 and $1298.15 \mathrm{~kg} \cdot \mathrm{m}^{-3}$ at 293.15 K, respectively [27]. It can be easily established that the glucose-based DESs have comparable densities that can be compared to other DESs and some common ILs.
Additionally, Hayyan et al. [28] measured the densities of ChCl-D-fructose DESs at different ratios (1:1; $1.5: 1 ; 2: 1 ; 2.5: 1)$, and reported that the values were less than $1340.00 \mathrm{~kg} \cdot \mathrm{m}^{-3}$. The density of these ChCl-D-fructose DES increased with the increase of the $\mathrm{ChCl}$ molar ratio. ChCl-D-fructose DES with the molar ratio 1:1 had the density of $1337.00 \mathrm{~kg} \cdot \mathrm{m}^{-3}$ at room temperature and $1226.90 \mathrm{~kg} \cdot \mathrm{m}^{-3}$ at $358.15 \mathrm{~K}$. ChCl-D-fructose DES with molar ratio $2.5: 1$ had the density of $1211.50 \mathrm{~kg} \cdot \mathrm{m}^{-3}$ at $358.15 \mathrm{~K}$. ChCl-D-fructose DES (molar ratio 1.5:1) had approximately a similar density range to the DES made of [methyltriphenylphosphonium bromide:glycerol] at the ratio of 1:1.75. IL [1-butyl-1-methylpyrrolidinium trifluoromethanesulfonate] had the density $1200.00 \mathrm{~kg} \cdot \mathrm{m}^{-3}$, very close to the density of ChCl-D-fructose DES (molar ratio 2.5:1) at room temperature [26]. Ionic liquid [1-amyl3-methylimidazolium hexafluorophosphate] had a high density $\left(1320.00 \mathrm{~kg} \cdot \mathrm{m}^{-3}\right)$, close to $\mathrm{ChCl}$-D-fructose DES (molar ratio 1:1) at room temperature [27]. However, ILs can have much higher density values, such as 2400.00 $\mathrm{kg} \cdot \mathrm{m}^{-3}$ reported for the IL $\left[\left(\mathrm{CH}_{3}\right)_{3} \mathrm{~S}\right]^{+}\left[\mathrm{Al}_{2} \mathrm{Br}_{7}\right]^{-}$[29]. It can be said that the D-fructose based DESs have similar densities to other reported DESs and ILs.

The expansion with temperature is best quantified by the thermal expansion coefficient $(\alpha)$, defined in equation (3) as:

$\alpha=-\frac{1}{\rho}\left(\frac{\partial \rho}{\partial T}\right)_{P}$

It can be obtained by the In $\rho$ - T plot, fitted according to the straight line from the equation (4):

$\ln \rho=c-\alpha \cdot T$

where $\mathrm{c}$ represents an empirical constant. Thermal expansion coefficients values are in the range of $3.1 \cdot 10^{-3} \mathrm{~K}^{-1}$ (for citric acid:glucose) and $8 \cdot 10^{-4} \mathrm{~K}^{-1}$ (for citric acid:fructose), as shown in Table 4. The studied DESs do not expand appreciably in the investigated temperature range. 
Table 4. Constants of the equation (4) for temperature dependence of thermal expansion coefficient, together with standard deviations $(\sigma)$, correlation factors (Adj. $\left.R^{2}\right)$ and temperature ranges for $(1: 1 \mathrm{M})$ citric acid:glucose and citric acid:fructose deep eutectic mixtures

\begin{tabular}{ccccccc}
\hline DES & Temp.range & \multicolumn{3}{c}{ Coefficients of Eq. (4) } & Adj. $\mathbf{R}^{2}$ \\
& $\mathbf{T}(\mathbf{K})$ & $\mathbf{c ~}\left(\mathbf{k g} \cdot \mathbf{m}^{-3} \cdot \mathbf{K}^{-1}\right)$ & $\boldsymbol{\sigma}[\mathbf{c}]$ & $\boldsymbol{\alpha}\left(\mathbf{K}^{-1}\right)$ & $\boldsymbol{\sigma}[\mathbf{\alpha}]$ & \\
\hline DES1 & $293.15-363.15$ & 8.3851 & $44.02 \cdot 10^{-4}$ & $3.1 \cdot 10^{-3}$ & $1.4 \cdot 10^{-5}$ & 0.9961 \\
& & & & & & \\
DES2 & $293.15-363.15$ & 7.5861 & $6.84 \cdot 10^{-4}$ & $8.0 \cdot 10^{-4}$ & $2 \cdot 10^{-6}$ & 0.9988
\end{tabular}

The molecular volume $\left(\mathrm{V}_{\mathrm{m}}\right)$ can be calculated by the equation (5):

$$
\mathrm{V}_{\mathrm{m}}=\frac{\mathrm{M}}{\mathrm{N}_{\mathrm{A}} \cdot \rho}
$$

where $\mathrm{M}$ is molar mass and $\mathrm{N}_{\mathrm{A}}$ is Avogadro's constant $\left(6.022 \cdot 10^{23} \mathrm{~mol}^{-1}\right)$. Also, the volume and density may be substituted for one another since they have the inverse mathematical relation (Eq. 6):

$\mathrm{V}_{\mathrm{m}}\left(\mathrm{nm}^{3}\right)=\frac{\mathrm{M}\left(\mathrm{g} \cdot \mathrm{mol}^{-1}\right)}{602.2 \cdot \rho\left(\mathrm{g} \cdot \mathrm{cm}^{-3}\right)}$

where the factor 602.2 derives from the Avogadro constant. The values of molecular volume at $303.15 \mathrm{~K}$ were found to be $0.3768 \mathrm{~nm}^{3}$ for citric acid:glucose (1:1) and $0.4204 \mathrm{~nm}^{3}$ for citric acid:fructose (1:1). Many properties correlate rather closely with the formula unit volume. Glasser [30] listed linear correlations observed between the formula volume and heat capacity, entropy, and lattice energy. The heat capacity and entropy correlations appear to be linear in formula volume, because larger volumes imply greater freedom of motion of the species involved. The smaller the distance between charges, the larger the lattice energy. Lattice energy is proportional to $V_{m}{ }^{-1 / 3}$ (where the ${ }^{1 / 3}$ exponent is needed to convert volume to distance). The lattice energy $\left(U_{\text {pot }}\right)$ was calculated according to the equation (7) [30-31]:

$U_{\text {pot }}=1981.2 \cdot\left(\frac{\rho}{M}\right)^{\frac{1}{3}}+103.8$

The lattice energy for the studied DESs were found

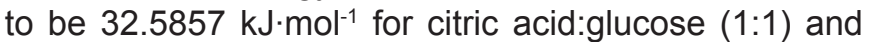
$31.4220 \mathrm{~kJ} \cdot \mathrm{mol}^{-1}$ for citric acid:fructose (1:1) at the same temperature $(303.15 \mathrm{~K})$. The obtained values for these DESs are lower than those of molten salts, namely, the fused CsI has the lowest lattice energy among the alkaline halides and the value is $613.00 \mathrm{~kJ} \cdot \mathrm{mol}^{-1}$ [32]. This is primarily the reason why these DESs can exist in a liquid state close to room temperature. Heat capacity $\left(C_{p}\right)$ was calculated according to the equation (8) for ionic liquids [30-31]:

$$
\mathrm{C}_{\mathrm{p}}=1037 \cdot \mathrm{V}_{\mathrm{mol}}+45
$$

The obtained $C_{p}$ values at $303.15 \mathrm{~K}$ are 435.7390 $\mathrm{J} \cdot \mathrm{K}^{-1} \cdot \mathrm{mol}^{-1}$ and $480.9343 \mathrm{~J} \cdot \mathrm{K}^{-1}$ for citric acid:glucose (1:1) and citric acid:fructose (1:1), respectively.
Effect of temperature on the dynamic viscosity of two citric acid-based deep eutectic solvents

Viscosity data is important for the industrial chemical process design, fluid flow systems and for selecting suitable applications. Viscosity data of DES can be helpful for the selection of optimum salt:hydrogen bond donor ratio, which can consequently save both material and energy. In general, at atmospheric pressure, the increase in temperature results in the increase of the average speed of the molecules in the liquid. This leads to a decrease in the average intermolecular forces and, consequently, reduces the fluid resistance to flow, termed as the viscosity. Basically, the viscosity of ILs is influenced by the strength of their van der Waals interactions, the hydrogen bonding ability, and the planarity of the molecular structure [33]. In their systematic study of the viscosity of ILs, Okoturo and Van der Noot [34] concluded that the temperature variation of viscosity of ILs follows the Arrhenius equation or Vogel-Tamman-Fulcher (VTF) equation.

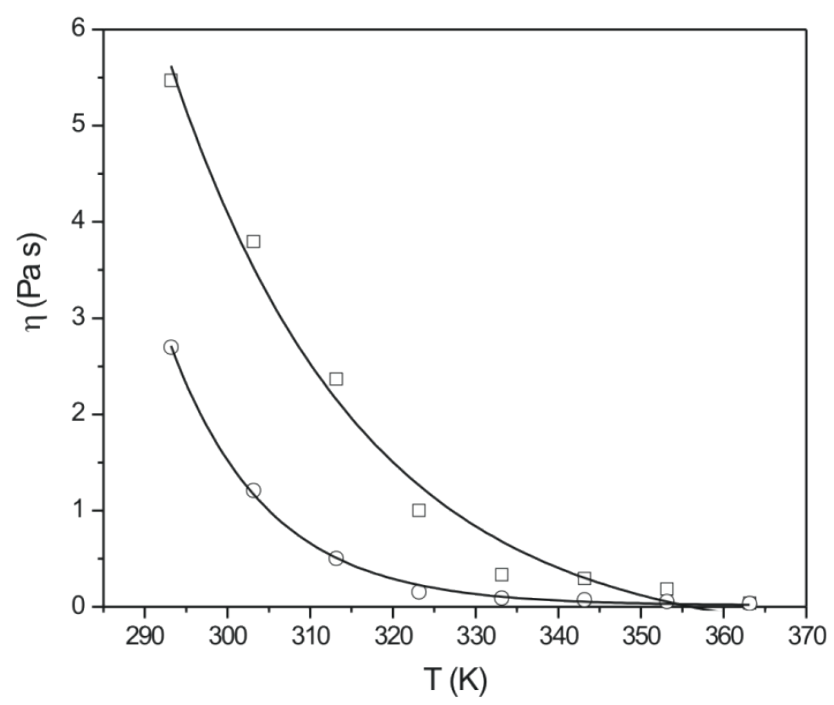

Figure 4. Temperature dependence of the dynamic viscosity of the studied eutectic mixtures: citric acid:glucose - $\square$ and citric acid:fructose - $\bigcirc$.

The effect of temperature on the viscosity of the ILs can be fitted by the Arrhenius equation, which represents a simplified version of Eyring's absolute rate theory, given by equation (9) [23]: 
$\eta=\eta_{\infty} \cdot \exp \left[\frac{-E_{a, \eta}}{R \cdot T}\right]$.

where $\eta_{\infty}, E_{a, \eta}, R$, and $T$ are constant for the given liquid, the activation energy for the viscous flow, the gas constant and the absolute temperature, respectively. Figure 4 shows dynamic viscosities ( $\eta$ ) of synthesized citric acid-based deep eutectic mixtures. As it has been observed for the density, the citric acid:fructose eutectic mixture has a notably lower dynamic viscosity than the citric acid:glucose eutectic mixture. Viscosity ( $\eta, P a \cdot s)$ is given as a temperature $(T, K)$ dependence as a polynomial equation of the third degree (10):

$$
\eta=a+b \cdot T+c \cdot T^{2}+d \cdot T^{3}
$$

By using Excel program (Microsoft Office), "a", "b", "c" and "d" parameters were obtained. The dynamic viscosity values for these DESs vary from 0.0370 to 5.4730 $\mathrm{Pa} \cdot \mathrm{s}$ (for citric acid:glucose) and from 0.0368 to 2.7000 $\mathrm{Pa} \cdot \mathrm{S}$ (for citric acid:fructose) for the temperature range of 293.15-363.15 K. It can be noticed that our systems have higher viscosity values on lower temperatures, but drop rapidly during heating.

Few studies reported the viscosity of ILs [10] and, in addition, DES physical properties data are even more lacking. DESs that are liquid at room temperature are both easy to handle and can be applied in many industrial routes [26]. DESs that have high viscosity are not a good choice for certain applications, like a liquid-liquid extraction. Also, viscous solvents need to be preheated before processing and require more pumping energy [35]. Hayyan et al. [25] reported that, at room temperature $\mathrm{ChCl-D-glucose}$ DES (molar ratio 2.5:1) had the highest viscosity value of $10.9100 \mathrm{~Pa} \cdot \mathrm{s}$, followed by ChCl-D-glucose DES (molar ratio 1:1) with the viscosity of $9.0371 \mathrm{~Pa} \cdot \mathrm{s}$. At $358.15 \mathrm{~K} \mathrm{ChCl-D-glucose} \mathrm{DESs}$ with molar ratios of $1: 1 ; 1.5: 1 ; 2: 1$; and $2.5: 1$ had the viscosities of $0.2093,0.1307,0.0720$, and $0.1083 \mathrm{~Pa} \cdot \mathrm{s}$, respectively. At $298.15 \mathrm{~K}$ these DESs had the viscosities of $9.0371,8.0000,8.0451$ and $10.9100 \mathrm{~Pa} \cdot \mathrm{s}$, re- spectively. D-glucose-based DESs are more viscous than some phosphonium-based DESs, especially at low temperatures. According to Kareem et al. [26], at 338.15 $\mathrm{K}$, the viscosity value of $0.0166 \mathrm{~Pa} \cdot \mathrm{s}$ was reported for [methyltriphenylphosphonium bromide:glycerol] DES in the ratio of $1: 1.75$, and $0.0054 \mathrm{~Pa} \cdot \mathrm{s}$ for [methyltriphenylphosphonium bromide:ethylene glycol] DES in the ratio of $1: 4$. In their study with $\mathrm{ChCl}$-based DESs with D-fructose in different molar ratios $(1: 1 ; 1.5: 1 ; 2: 1 ; 2.5: 1)$, Hayyan et al. [28] noted that at room temperature $\mathrm{ChCl}$ based DESs with D-fructose (molar ratio 2.5:1) had the highest viscosity of $17.6455 \mathrm{~Pa} \cdot \mathrm{s}$, followed by $\mathrm{ChCl}$ D-fructose DES with the molar ratio of 1.5:1 (14.3474 $\mathrm{Pa} \cdot \mathrm{s})$. At 358.15, $\mathrm{K} \mathrm{ChCl-D-fructose} \mathrm{DESs}$ in different molar ratios $(1: 1 ; 1.5: 1 ; 2: 1 ; 2.5: 1)$ had the viscosities in the range of $0.1293-0.2806 \mathrm{~Pa} \cdot \mathrm{s}$. The lowest viscosity at room temperature and at high temperature was reported for ChCl-D-fructose DES with molar ratio of 2:1. The authors recommended that, in order to reduce their viscosity, D-fructose based DESs need to be heated to higher temperatures, such as $318.15-328.15 \mathrm{~K}$ or even to $338.15 \mathrm{~K}$. D-fructose based DESs are much viscous than other phosphonium-based DESs reported by other studies [26].

If it is assumed that the fluid flow obeys the Arrhenius equation [36-37], the temperature dependence of liquid viscosity can also be expressed exponentially, as in equation (11):

$$
\eta=A_{\eta} \cdot e^{\frac{E_{\eta}}{R \cdot T}}
$$

where $A_{\eta}$ is the pre-exponential factor, $E_{\eta}$ is the activation energy for viscosity, $T$ is absolute temperature $(K)$, and $R$ is the universal gas constant $\left(8.314 \mathrm{~J} \cdot \mathrm{K}^{-1} \cdot \mathrm{mol}^{-1}\right)$. The pre-exponential factor, $\mathrm{A} \eta$, is the frequency factor and describes molecular collisions in the collision theory and the entropy term in the transition state theory. The activation energy $E_{\eta}$ is an energy barrier that must be overcome before the elementary flow process can occur. Table 5 presents these equations for dynamic viscosities of both studied DESs.

Table 5. Polynomial and exponential viscosity equations together with temperature ranges and correlation factors for $(1: 1 \mathrm{M})$ citric acid:glucose and citric acid:fructose deep eutectic mixtures

\begin{tabular}{cccc}
\hline DES & $\begin{array}{c}\text { Temp. range } \\
\mathbf{T}(\mathbf{K})\end{array}$ & $\begin{array}{c}\text { Viscosity equation } \\
\boldsymbol{\eta}(\mathbf{P a} \cdot \mathbf{s})\end{array}$ & Adj. $^{\mathbf{R}^{2}}$ \\
\hline DES1 & $293.15-363.15$ & $\eta=-9 \cdot 10^{-6} \cdot \mathrm{T}^{3}+0.0104 \cdot \mathrm{T}^{2}-4.0100 \cdot \mathrm{T}+513.65$ & 0.9880 \\
& & $\eta=2 \cdot 10^{-10} \mathrm{e}^{7222.8(1 / \mathrm{T})}$ & 0.9008 \\
DES2 & $293.15-363.15$ & $\eta=-2 \cdot 10^{-5} \cdot \mathrm{T}^{3}+0.0251 \cdot \mathrm{T}^{2}-8.5833 \cdot \mathrm{T}+978.02$ & 0.9944 \\
& & $\eta=3 \cdot 10^{-10} \mathrm{e}^{6634.2(1 / \mathrm{T})}$ & 0.9199 \\
\hline
\end{tabular}


The logarithmic form of the Arrhenius equation can also be used in order to describe the temperature dependence of viscosity, presented as in equations (12) and (13):

$$
\log \eta=\log A_{\eta}+\frac{E_{\eta}}{2.303 \cdot R \cdot T}
$$

or

$$
\ln \eta=\ln \eta_{0}+\frac{E_{\eta}}{R \cdot T}
$$

It is obvious that the $\log \eta$ or $\ln \eta$ must also be a linear function of the reciprocal of the absolute temperature $(1 / T)$. From the slope and intercept of the straight line, $A_{\eta}$ and $E_{\eta}$ can be calculated. The viscosity-temperature dependence can be fitted by the Arrhenius equation with high precision for studied deep eutectic mixtures, as shown in Table 6.

Table 6. Arrhenius equations for viscosity with calculated pre-exponential factors and activation energies for DESs

\begin{tabular}{cccccc}
\hline DES & $\begin{array}{c}\text { Temp. range } \\
\mathbf{T}(\mathbf{K})\end{array}$ & $\begin{array}{c}\text { Viscosity Arrhenius Equations } \\
\text { ( } \boldsymbol{\eta} \text { in Pa.s) }\end{array}$ & $\begin{array}{c}\mathbf{A}_{\eta} \\
(\mathbf{P a} \cdot \mathbf{s})\end{array}$ & $\begin{array}{c}\mathbf{E}_{\eta} \\
\left(\mathbf{J} \cdot \mathbf{m o l} \mathbf{l}^{-1}\right)\end{array}$ & ${\text { Adj. } \mathbf{R}^{2}}$ \\
\hline DES1 & $293.15-363.15$ & In $\eta=7222.8 \cdot(1 / T)-22.542$ & $1.6223 \cdot 10^{-10}$ & 60050.36 & 0.9406 \\
DES2 & $293.15-363.15$ & In $\eta=6634.2 \cdot(1 / T)-21.884$ & $3.1326 \cdot 10^{-10}$ & 55156.74 & 0.9523 \\
\hline
\end{tabular}

As expected, $E_{\eta}$ values for eutectic mixtures tested are larger than those for conventional liquids or high temperature molten salts [36-37], which can be explained by large ion to the hole radius ratio in these eutectic mixtures. The difference observed between the two DESs studied must arise from a better ability of monosaccharides to form hydrogen bonds through their chemical groups, which may explain differences in density and viscosity. It was previously stated by other authors [38] that alkyl chain lengthening or fluorination of organic components causes the increase in van der Waals interactions and hydrogen bonds, which makes ionic liquids be more viscous. Since high viscosity at low temperatures can negatively affect any technological process, it is recommended to use these DESs at the temperature not lower than $323.15 \mathrm{~K}$.

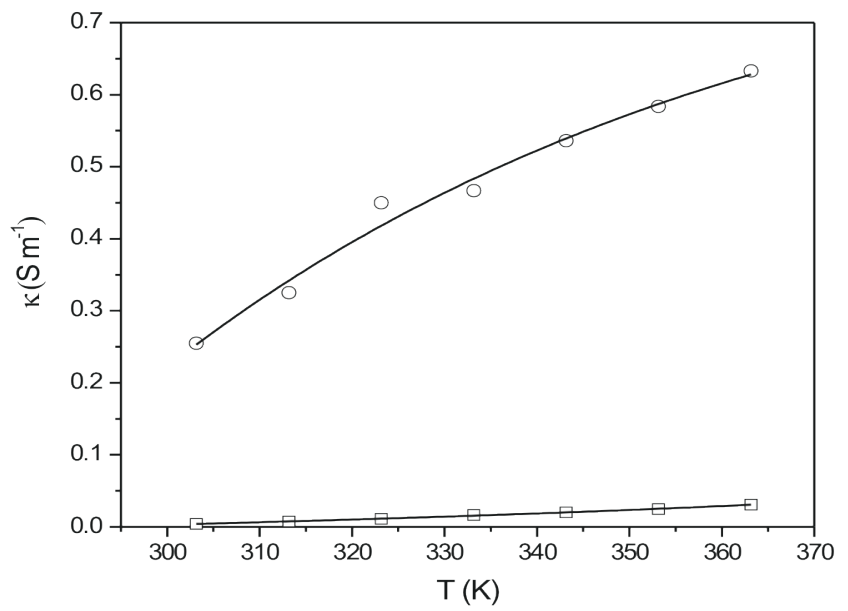

Figure 5. Temperature dependence of the conductivity of the studied eutectic mixtures: citric acid:glucose - $\square$ and citric acid:fructose - $\circ$.
Effect of temperature on the electrical conductivity of two citric acid-based deep eutectic solvents

The electrical conductivity of an IL $(\mathrm{K})$ is very important if it is considered to be a supporting electrolyte in electrochemical devices. The higher conductivity exhibited the lower ohmic drop during electrolysis and lower cell voltage, resulting in higher energy efficiency. For ILs the temperature-electrical conductivity dependence is described by the Arrhenius-type equation (14) [33]:

$\kappa=\kappa_{\infty} \cdot \exp \left[\frac{-E_{a, \kappa}}{k_{B} \cdot T}\right]$

where $\mathrm{K}_{\infty}, \mathrm{E}_{\mathrm{a}, \mathrm{K}}, \mathrm{k}_{\mathrm{B}}$, and $\mathrm{T}$ are electrical conductivity at infinite temperature, activation energy (energy needed for an ion to hop in a free hole), the Boltzmann constant, and absolute temperature, respectively. On the other hand, the conduction behaviour of most of the ILs does not follow the exponential dependence with the inverse of the temperature. The observed conductivity vs. temperature relationship can be described by VTF-type equation (15): $\kappa=\kappa_{\infty} \cdot \exp \left[\frac{-E_{a, \kappa}}{k_{B} \cdot\left(T-T_{g}\right)}\right]$

where $T_{g}$ stands for the glass transition temperature. The equation can be also written as (16):

$\kappa=\kappa_{0} \cdot \exp \left[\frac{-B^{\prime}}{\left(T-T_{0}\right)}\right]$

where $\mathrm{K}_{0}, \mathrm{~B}^{\prime}$, and $\mathrm{T}_{0}$ represent the VTF fitting parameters. The plots of electrical conductivity values for the two deep eutectic mixtures as a function of temperature over the temperature range of $303.15-363.15 \mathrm{~K}$ are shown in Figure 5. The values of electrical conductivity increase with temperature for both investigated eutectic mixtures in the range of $0.00421-0.03090 \mathrm{~S} \cdot \mathrm{m}^{-1}$ for eutectic mixture citric acid:glucose $(1: 1)$ and in the range of 0.25500 $0.63300 \mathrm{~S} \cdot \mathrm{m}^{-1}$ for eutectic mixture citric acid:fructose $(1: 1)$. 
The figure clearly shows that the change in the electrical conductivity of eutectic mixture citric acid:fructose $(1: 1)$ is significant, while in the case of eutectic mixture citric acid:glucose (1:1) electrical conductivity changes very little with temperature.

Polynomial equations of second degree (17) expressing the temperature dependence of electrical conductivity $\left(\mathrm{K}, \mathrm{S} \cdot \mathrm{m}^{-1}\right)$ is shown as:

$\kappa=a+b \cdot T+c \cdot T^{2}$

where $T$ represents the temperature $(K)$. Also, the temperature dependence of electrical conductivity can also be expressed exponentially by using the Arrhenius equation (18):

$\kappa=A_{\kappa} \cdot e^{\frac{-E_{\kappa}}{R \cdot T}}$ where: Aк represents the pre-exponential coefficient, Ek represents the activation energy for electrical conduction, $T$ represents absolute temperature $(\mathrm{K})$, and $\mathrm{R}$ represents the universal gas constant $\left(8.314 \mathrm{~J} \cdot \mathrm{K}^{-1} \cdot \mathrm{mol}^{-1}\right)$. These equations for electrical conductivity of both studied ionic liquids are presented in Table 7. As previously done with viscosity data, the electrical conductivity of deep eutectic mixtures can also be fitted using the logarithmic form of Arrhenius equation (equations (19-20)) [39-40]:

$$
\log \kappa=\log A_{\kappa}-\frac{E_{\kappa}}{2.303 \cdot R \cdot T}
$$

or

$$
\ln \kappa=\ln \kappa_{0}-\frac{E_{\kappa}}{R \cdot T}
$$

Table 7. Polynomial and exponential conductivity equations together with the temperature ranges and correlation factors for DESs $(1: 1 \mathrm{M})$ citric acid:glucose and citric acid:fructose

\begin{tabular}{cccc}
\hline DES & $\begin{array}{c}\text { Temp. range } \\
\mathbf{T}(\mathbf{K})\end{array}$ & $\begin{array}{c}\text { Conductivity equations } \\
\mathbf{K}\left(\mathbf{S} \cdot \mathbf{m}^{-1}\right)\end{array}$ & Adj. $\mathbf{R}^{\mathbf{2}}$ \\
\hline DES1 & $303.15-363.15$ & $\mathrm{~K}=2 \cdot 10^{-6} \cdot \mathrm{T}^{2}-0.0009 \cdot \mathrm{T}+0.1002$ & 0.9954 \\
& & $\mathrm{~K}=629.460 \cdot \mathrm{e}^{-3567(1 / \mathrm{T})}$ & 0.9576 \\
DES2 & $303.15-363.15$ & $\mathrm{~K}=-5 \cdot 10^{-5} \cdot \mathrm{T}^{2}+0.0368 \cdot \mathrm{T}-6.6854$ & 0.9698 \\
& & $\mathrm{~K}=58.983 \cdot \mathrm{e}^{-1622(1 / \mathrm{T})}$ & 0.8900 \\
\hline
\end{tabular}

Table 8. Arrhenius equations for conductivity with calculated pre-exponential factors and activation energies for DESs

\begin{tabular}{cccccc}
\hline DES & $\begin{array}{c}\text { Temp. range } \\
\mathbf{T}(\mathbf{K})\end{array}$ & $\begin{array}{c}\text { Electrical Conductivity } \\
\text { Arrhenius Equations } \\
\left(\mathbf{K}, \mathbf{S} \cdot \mathbf{m}^{-1}\right)\end{array}$ & $\begin{array}{c}\mathbf{A}_{\mathbf{k}} \\
\left(\mathbf{S} \cdot \mathbf{m}^{-1}\right)\end{array}$ & $\begin{array}{c}\mathbf{E}_{\mathbf{k}} \\
\left(\mathbf{J} \cdot \mathbf{m o l}^{-1}\right)\end{array}$ & Adj. $^{\mathbf{2}}$ \\
& & & & & \\
\hline DES1 & $303.15-363.15$ & $\ln \mathrm{K}=-3567.3 \cdot 1 / \mathrm{T}+6.4449$ & 629.4837 & 29658.53 & 0.9743 \\
DES2 & $303.15-363.15$ & $\ln \mathrm{K}=-1622.3 \cdot 1 / \mathrm{T}+4.0773$ & 58.9860 & 13487.80 & 0.9320 \\
\hline
\end{tabular}

Thermodynamic functions of activation of two citric acid-based deep eutectic solvents

In order to understand the viscous flow better, Eyring's transition state theory was used for calculating the thermodynamic functions of activation from the dynamic viscosity. For liquid mixtures, the expression (21) for the dynamic viscosity can be written as $[41,42]$ :

$\eta=\left(\frac{h \cdot N_{A}}{V}\right) \cdot e^{\frac{\Delta G^{*}}{R \cdot T}}$

where: $\mathrm{h}$ represents the Planck's constant; NA represents Avogadro's number; $V$ represents the molar volume of the eutectic mixture (the ratio of the average molar mass and density of the eutectic mixture); $\Delta G^{*}$ represents the molar Gibbs energy of activation for the viscous flow process. Combining the previous equation with equation (22):
$\Delta \mathrm{G}^{*}=\Delta \mathrm{H}^{*}-\mathrm{T} \cdot \Delta \mathrm{S}^{*}$

yields the equation (23):

$\ln \left(\frac{\eta \cdot V}{h \cdot N_{A}}\right)=\left(\frac{\Delta H^{*}}{R \cdot T}\right)-\left(\frac{\Delta S^{*}}{R}\right)$

From the experimental density and viscosity data, it is possible to calculate $\ln \left(\eta \cdot V / h \cdot N_{A}\right)$ as a function of $1 / T$ for each system (Figure 6). From slope and intercept of the straight lines, the enthalpy $\left(\Delta \mathrm{H}^{*}\right)$ and entropy $\left(\Delta \mathrm{S}^{*}\right)$ of activation of viscous flow were calculated. The $\Delta \mathrm{H}^{*}$ values were constant in the studied temperature range. 


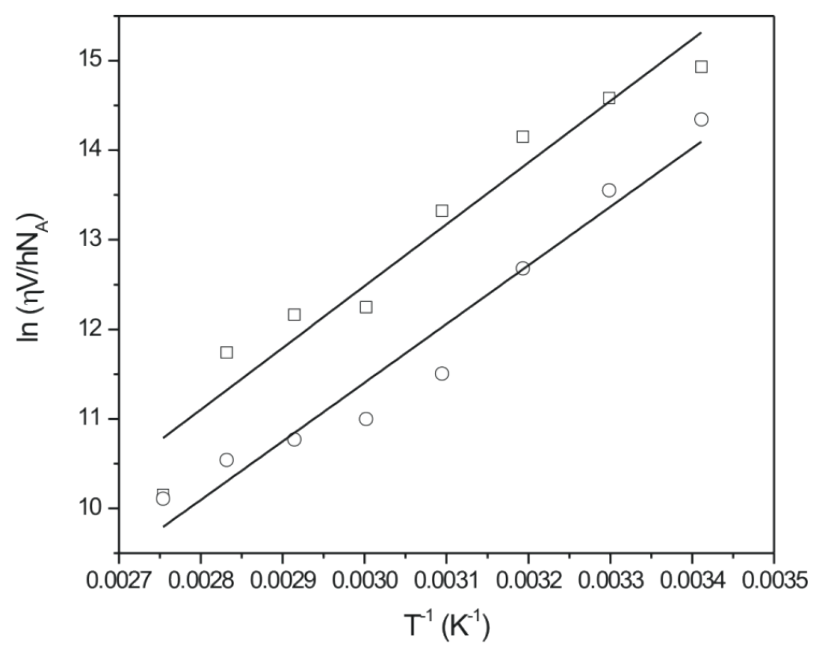

Figure 6. Plots of $\ln \left(\eta \cdot V / h \cdot N_{A}\right)$ against the inverse temperature of the studied eutectic mixtures: citric acid:glucose - $\square$ and citric acid:fructose - $\circ$.

Table 9. The thermodynamic functions of activation of viscous flow, $\Delta \mathrm{H}^{*}, \Delta \mathrm{S}^{*}, \Delta \mathrm{G}^{*}$, and coefficients of correlation for tested DESs at $303.15 \mathrm{~K}$

\begin{tabular}{cccccc}
\hline DES & Eyring's Eq. & $\Delta \mathbf{H}^{*}\left(\mathbf{k J} \cdot \mathbf{m o l}^{-1}\right)$ & $\mathbf{T} \cdot \mathbf{\Delta} \mathbf{S}^{*}\left(\mathbf{k J} \cdot \mathbf{m o l}^{-1}\right)$ & $\begin{array}{c}\Delta \mathbf{G}^{*} \\
\left(\mathbf{k J} \cdot \mathbf{m o l}^{-1}\right)\end{array}$ & Adj. $\mathbf{R}^{\mathbf{2}}$ \\
\hline DES1 & In $\left(\eta \cdot \mathrm{V} / \mathrm{h} \cdot \mathrm{N}_{\mathrm{A}}\right)=6892.7 \cdot 1 / \mathrm{T}-$ & 57.3060 & 20.6546 & 36.6513 & 0.9365 \\
& 8.1950 & & & & \\
& & & & & \\
DES2 & In $\left(\eta \cdot \mathrm{V} / \mathrm{h} \cdot \mathrm{N}_{\mathrm{A}}\right)=6548.2 \cdot 1 / \mathrm{T}-$ & 54.4417 & 20.7683 & 33.6735 & 0.9506 \\
& 8.2401 & & & & \\
\hline
\end{tabular}

Table 9 contains obtained values of thermodynamic functions of activation at $303.15 \mathrm{~K}$, together with the coefficients of correlation for the fits to equation (23). It can be seen that the magnitude of molar enthalpy of activation for viscous flow is higher than $T \cdot \Delta S^{*}$ values. We can conclude that the energetic contribution, which corresponds to the molar enthalpy of activation for viscous flow, is more important than the entropic contribution terms to the molar Gibbs energy of activation for viscous flow values. For these two investigated systems, the interactional factor is predominant over structural for the viscous flow process.

Relationship between molar conductivity and viscosity

The relation between ionic conductivity and molar conductivity is given by the equation (24):

$\Lambda=\frac{\kappa \cdot M}{\rho}$

where $\Lambda$ is the molar conductivity, $k$ is the ionic conductivity, $\rho$ is the density and $M$ is the average molecular weight. The empirical VTF equation for the observed temperature dependences of molar conductivity (25) can be expressed as:
$\Lambda=\Lambda_{0} \cdot \exp \left[\frac{-\mathrm{B}^{\prime}}{\left(\mathrm{T}-\mathrm{T}_{0}\right)}\right]$

where $\wedge$, B', and To represent the VTF fitting parameters [33]. The relation between mobility of ions and viscosity is given by Walden rule $(\lambda \cdot \eta=$ const; $\lambda$ is the equivalent conductivity). If the manner of dissociation of a solute constituting an electrolytic solution is not known, the molar conductivity rather than the equivalent conductivity is used. Interestingly enough, the original Walden rule finds a new lease on life in current studies of ionic liquids of the ambient temperature variety, where the Walden plot, in the form log $(\Lambda)$ versus $\log \left(\eta^{-1}\right)$ is being used as a classification diagram to distinguish "normal" ionic liquids from "poor" ionic liquids, on the one hand, and "superionic" liquids on the other hand [43]. The Walden rule is useful for organizing and classifying the ILs [44]. For molten salts and ionic liquids it was found that it is more appropriate to use the "fractional" Walden rule, shown as equations (26-27):

$\Lambda \cdot \eta^{\alpha}=\mathrm{C}$

or

$\log \Lambda=\log C+\alpha \cdot \log \eta^{-1}$ 
In this equations $C$ is a temperature dependent constant called the Walden product, and $\alpha$ is a positive constant smaller than 1 , representing the slope of the line in the Walden plot, which reflects the decoupling of the ions. The parameter a expresses the difference of the activation energies of the ionic conductivity and viscosity $[43,45,46]$. The variation of $\log \wedge v$ s. $\log \eta^{-1}$ is shown in Figure 7.

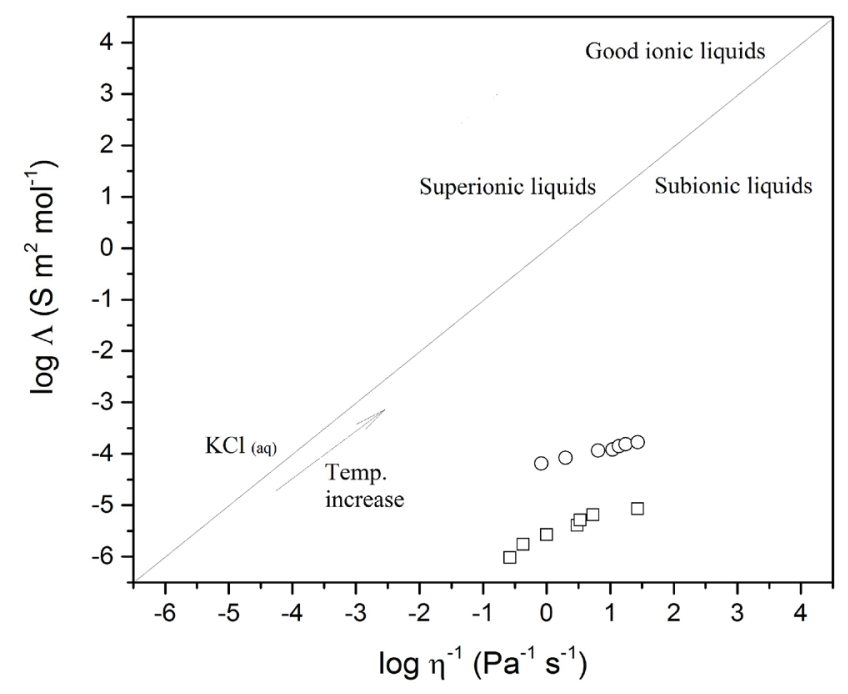

Figure 7. The application of fractional Walden rule for the studied DESs (citric acid:glucose - $\square$ and citric acid:fructose - $\circ$ ). For the ideal dotted Walden line, the data for dilute aqueous $0.01 \mathrm{M} \mathrm{KCl}$ solution [47], comprising of equal mobilities of fully dissociated ions [48] were used.
The fractional Walden rule, which implies that the Arrhenius activation energy for conductivity is lower than that for viscosity, finds a natural interpretation in terms of one of the ionic species being smaller than the other, hence capable of squeezing through smaller gaps in the condensed phase structure. All the studied DESs obey the fractional Walden rule very well and the values of the Walden slopes are all smaller than unity (see Table 10), indicating the presence of obvious ion associations in the investigated DESs.

From Figure 7, it is obvious that the curves of the studied DESs are under the ideal line [46]. To fix the position of the ideal dotted Walden line from corner to corner of a square diagram in Fig. 7, the data for dilute aqueous $\mathrm{KCl}$ solution [47], comprising of equal mobilities of fully dissociated ions [48], were used. Another way used for calculating the $\alpha$ is the ratio of the temperature-dependent activation energies for viscosity and molar conductivity $\left(\alpha=E_{a, \Lambda} / E_{a, \eta}<1\right)$. These results mean that in the investigated DESs there are not only charge carrying species simply formed by citric acid, because if that was the case all slopes would have to be similar. In the case under discussion, it is likely that the conduction here involves some degree of cooperation of the ions concerned. Here lies a resemblance to the process of the viscous flow from molten salts, where due to the imposed condition of electroneutrality the translation of ions of both signs is involved. But because all the investigated DESs are under the ideal line, this shows that these ILs are also "subionic", and we believe that their special accumulation structure also account for this phenomenon.

Table 10. Walden equation coefficients along with the standard deviations $(\sigma)$, regression coefficients (Adj. $\mathrm{R}^{2}$ ) and the temperature ranges for the DESs

\begin{tabular}{|c|c|c|c|c|c|c|}
\hline \multirow[t]{2}{*}{ DES } & \multirow{2}{*}{$\begin{array}{c}\text { Temp.range } \\
\mathrm{T}(\mathrm{K})\end{array}$} & \multicolumn{4}{|c|}{ Coefficients of Walden Eq. } & \multirow[t]{2}{*}{ Adj. $R^{2}$} \\
\hline & & $\alpha$ & $\sigma[\alpha]$ & c & $\sigma[c]$ & \\
\hline DES1* & $303.15-363.15$ & 0.4690 & 0.1130 & $2.4155 \cdot 10^{-6}$ & $4.8823 \cdot 10^{-7}$ & 0.9103 \\
\hline DES2* & $303.15-363.15$ & 0.2726 & 0.0156 & $6.8108 \cdot 10^{-5}$ & $2.3426 \cdot 10^{-6}$ & 0.9874 \\
\hline
\end{tabular}

The esterification of oleic acid in the presence of eu tectic mixture citric acid: glucose (1:1) with the use of sulfuric acid as a catalyst

Figure 8 presents the change in the conversion of oleic acid into the ethyl oleate $\left(\mathrm{X}_{\mathrm{A}}\right)$ with the use of catalyst sulfuric acid ( $1 \%$ relative to the weight of oleic acid), as function of reaction time. Neither DES1 nor DES2 proved to be catalysts when used solely in the reaction. Although the reaction has a better start when DESs are present in the reaction mixture, and DES2 gives a better conversion degree of oleic acid into ethyl oleate than DES1, clearly it is better when these DESs are ex- cluded from the reaction mixture. We assume that the interaction of eutectic mixture with the reactants (oleic acid, ethyl alcohol and sulfuric acid) is low, but that the slowdown of the reaction in the presence of a eutectic mixture may be caused due to the increase in viscosity after the addition of the eutectic solvent. 


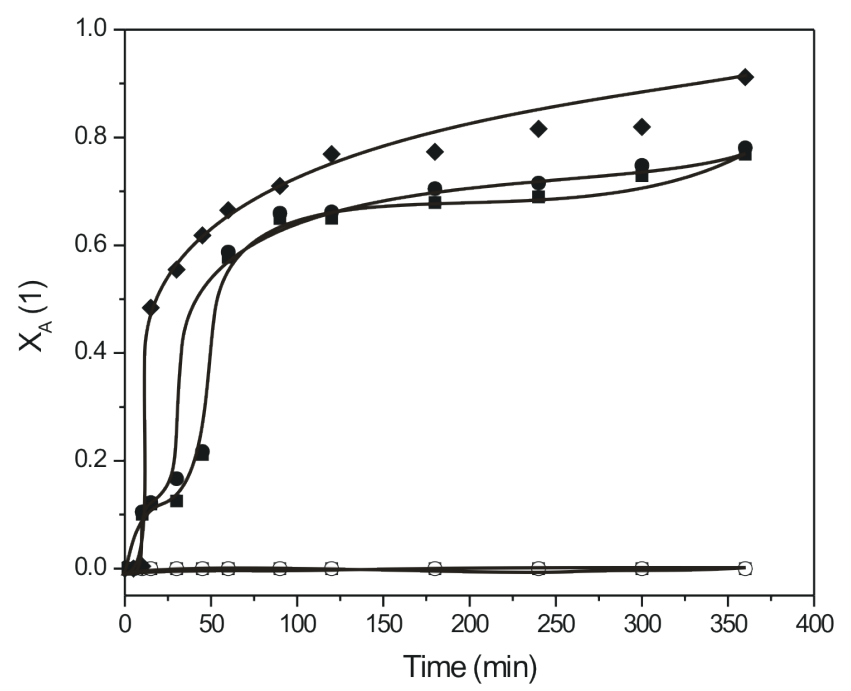

Figure 8. The influence of the citric acid-based DESs on the conversion degree of oleic acid into ethyl oleate $\left(\mathrm{X}_{\mathrm{A}}\right)$ with the use of sulfuric acid (1\% to the weight of oleic acid) as a catalyst ( $-\mathrm{H}_{2} \mathrm{SO}_{4}$ with DES1; $-\mathrm{H}_{2} \mathrm{SO}_{4}$ with DES2; $\square$ - DES1; $\circ-$ DES2; - $\mathrm{H}_{2} \mathrm{SO}_{4}$ )

\section{Conclusions}

There is an intermolecular interaction among the components of binary mixtures of citric acid and glucose or fructose leading to the formation of deep eutectic mixtures. These mixtures can be promising alternatives to classical ionic liquids because of the easy synthesis, availability and biodegradability of the components. In this paper, the densities, viscosities and electrical conductivities of the citric acid-based deep eutectic solvents with monosaccharides D-glucose or D-fructose, respectively, in 1:1 molar ratio, were measured as a function of temperature in the range 293.15-363.15 $\mathrm{K}$ at atmospheric pressure. In the investigated temperature range, in both cases of deep eutectic solvents, the density and viscosity of the systems decreases linearly with temperature, while the electrical conductivity increases. The viscosity and conductivity values of these DESs show classical Arrhenius behaviour, and these values are determined by the strength of the interactions present in the compounds, namely Van der Waals forces and hydrogen bonds. For these DESs, the absolute rate approach of Eyring theory concerning the viscosity flow shows that the interactional factor is predominant over the structural factor. The density and viscosity values were used in determining the thermal expansion coefficient, molecular volume, lattice energy and heat capacity of these DESs. The fractional Walden rule was applied in establishing the relationship between the density, viscosity and conductivity. Physical properties of citric acid-based DESs are similar to some ionic liquids. Since it is noticed that the studied DESs have high viscosity and density at room temperature, industrially it is recommended to heat up these DESs before processing. Despite the fact that these DESs were proven not to be good cosolvents in oleic acid ethanolysis, the authors hope that the future application of these DESs will be found and successfully achieved.

\section{Acknowledgements}

This work has been funded by the Ministry of Education, Science and Technological Development of the Republic of Serbia (Project III 45001).

\section{References}

[1] T. Welton, Room-temperature ionic liquids: solvents for synthesis and catalysis, Chemical Reviews, 99(8) (1999) $2071-2083$.

[2] H. Zhao, G. A. Baker, lonic liquids and deep eutectic solvents for biodiesel synthesis: a review, Journal of Chemical Technology and Biotechnology, 88(1) (2013) 3 12.

[3] T. Welton, lonic liquids in catalysis, Coordination Chemistry Reviews, 248(21-24) (2004) 2459 - 2477.

[4] A. Balducci, A. W. Henderson, M. Mastragostino, S. Passerini, P. Simon, F. Soavi, Cycling stability of a hybrid activated carbon//poly(3-methylthiophene) supercapacitor with N-butyl-N-methylpyrrolidinium bis(trifluoromethanesulfonyl)imide ionic liquid as electrolyte, Electrochimica Acta, 50(11) (2005) 2233 - 2237.

[5] R. Hagiwara, T. Nohira, K. Matsumoto, Y. Tamba, A fluorohydrogenate ionic liquid fuel operating without humidification, Electrochemical and Solid-State Letters, 8(4) (2005) 231 - 233.

[6] Y. Y. Jiang, H. S. Xia, C. Guo, H. Z. Liu, Phenomena and mechanism for separation and recovery of penicillin in ionic liquids aqueous solution, Industrial \& Engineering Chemistry Research, 46(19) (2007) 6303 - 6312.

[7] X. M. Hou, F. Zhou, Y. B. Sun, W. M. Liu, Ultrasoundassisted synthesis of dentritic $\mathrm{ZnO}$ nanostructure in ionic liquid, Materials Letters, 61(8-9) (2007) 1789 - 1792.

[8] Y. Y. Jiang, C. Guo, H. S. Xia, I. Mahmood, C. Z. Liu, H. Z. Liu, Magnetic nanoparticles supported ionic liquids for lipase immobilization: enzyme activity in catalyzing esterification, Journal of Molecular Catalysis B: Enzymatic, 58(1-4) (2009) 103 - 109.

[9] A. P. Abbott, G. Capper, D. L. Davies, R. K. Rasheed, V. Tambyrajah, Novel solvent properties of choline chloride/ urea mixtures, Chemical Communications, 9(1) (2003) 70 $-71$.

[10] A. P. Abbott, D. Boothby, G. Capper, D. L. Davies, R. K Rasheed, Deep eutectic solvents formed between choline chloride and carboxylic acids: versatile alternatives to ionic liquids, Journal of the American Chemical Society, 126(29) (2004) 9142 - 9147.

[11] A. P. Abbott, K. J. McKenzie, Application of ionic liquids to the electrodeposition of metals, Physical Chemistry Chemical Physics, 8(37) (2006) 4265 - 4279.

[12] Y. Dai, J. van Spronsen, G.-J. Witkamp, R. Verpoorte, Y. $\mathrm{H}$. Choi, Natural deep eutectic solvents as new potential media for green technology, Analytica Chimica Acta, 766 (2013) $61-68$.

[13] G. Imperato, E. Eibler, J. Niedermaier, B. König, Lowmelting sugar-urea-salt mixtures as solvents for Diels-Alder reactions, Chemical Communications, 36(9) (2005) 1170 $-1172$. 
[14] S. Gore, S. Baskaran, B. König, Efficient synthesis of 3,4-dihydropyrimidin-2-ones in low melting tartaric acidurea mixtures, Green Chemistry, 13(4) (2011) 1009 - 1013.

[15] F. Ilgen, B. König, Organic reactions in low melting mixtures based on carbohydrates and L-carnitine - a comparison, Green Chemistry, 11(6) (2009) 848 - 854.

[16] A. P. Abbott, J. Collins, I. Dalrymple, R. C. Harris, R. Mistry, F. Qiu, J. Scheirer, W. R. Wise, Processing of electric arc furnace dust using deep eutectic solvents, Australian Journal Of Chemistry, 62(4) (2009) 341 - 347.

[17] C. A. Nkuku, R. J. LeSuer, Electrochemistry in deep eutectic solvents, The Journal of Physical Chemistry B 111(46) (2007) 13271 - 13277.

[18] M. Figueiredo, C. Gomes, R. Costa, A. Martins, C. M. Pereira, F. Silva, Differential capacity of a deep eutectic solvent based on choline chloride and glycerol on solid electrodes, Electrochimica Acta, 54(9) (2009) 2630 - 2634

[19] H. R. Jhong, D. S. H. Wong, C. C. Wan, Y. Y. Wang, T. C. Wei, A novel deep eutectic solvent-based ionic liquid used as electrolyte for dye-sensitized solar cells, Electrochemistry Communications, 11(1) (2009) 209 - 211

[20] J. T. Gorke, F. Srienc, R. J. Kazlauskas, Hydrolasecatalyzed biotransformations in deep eutectic solvents, Chemical Communications, 10(10) (2008) 1235 - 1237.

[21] O. S. Stamenković, M. L. Lazić, Z. B. Todorović, V. B. Veljković, D. U. Skala, The effect of agitation intensity on alkali-catalyzed methanolysis of sunflower oil, Bioresource Technology, 98(14) (2007) 2688-2699.

[22] H. Rodriguez, J. F. Brennecke, Temperature and composition dependence of the density and viscosity of binary mixtures of water + ionic liquid, Journal of Chemical \& Engineering Data, 51(6) (2006) 2145-2155.

[23] J. Jacquemin, P. Husson, A. A. H. Padua, V. Majer, Density and viscosity of several pure and water-saturated ionic liquids, Green Chemistry, 8(2) (2006) 172 - 180.

[24] E. Gómez, B. González, A. Domínguez, E. Tojo, J. Tojo, Dynamic viscosities of a series of 1-alkyl-3methylimidazolium chloride ionic liquids and their binary mixtures with water at several temperatures, Journal of Chemical \& Engineering Data, 51(2) (2006) 696 - 701.

[25] A. Hayyan, F. S. Mjalli, I. M. AlNashef, Y. M. Al-Wahaibi, T. Al-Wahaibi, M. Ali Hashim, Glucose-based deep eutectic solvents: Physical properties, Journal of Molecular Liquids, 178 (2013) 137 - 141.

[26] M. A. Kareem, F. S. Mjalli, M. A. Hashim, I. M. AINashef, Phosphonium-based ionic liquids analogues and their physical properties. Journal of Chemical \& Engineering Data, 55(11) (2010) 4632 - 4637.

[27] S. Zhang, X. Lu, Q. Zhou, X. Li, X. Zhang, S. Li, Ionic liquids: Physicochemical properties, Elsevier, Oxford, 2009, p. 520

[28] A. Hayyan, F. S. Mjalli, I. M. AINashef, T. Al-Wahaibi, Y. M. Al-Wahaibi, M. Ali Hashim, Fruit sugar-based deep eutectic solvents and their physical properties, Thermochimica Acta, 541 (2012) 70 - 75.

[29] J. L. Anthony, J. F. Brennecke, J. D. Holbrey, E. J. Maginn, R. Mantz, R. D. Rogers, P. C. Trulove, A. E. Visser, T. Welton, in: Ionic liquids in synthesis; P. Wasserscheid, T. Welton Eds., Wiley-VCH Verlag, Weinheim, 2003, p.41

[30] L. Glasser, Thermodynamic estimation: Ionic materials, Journal of Solid State Chemistry, 206 (2013) 139 - 144.

[31] P. K. Chhotaray, S. Jella, R. L. Gardas, Physicochemical properties of low viscous lactam based ionic liquids, The Journal of Chemical Thermodynamics, 74 (2014) 255 - 262.
[32] W. M. Haynes, CRC Handbook of Chemistry and Physics, in: A ready reference book of chemical and physical data, 94th ed., CRC Press, Taylor \& Francis Group, Boca Raton, FI, USA, 2013.

[33] I-W. Sun, Y.-C. Lin, B.-K. Chen, C.-W. Kuo, C.-C. Chen, S.-G. Su, P.-R. Chen, T.-Y. Wu, Electrochemical and physicochemical characterizations of butylsulfate-based ionic liquids, International Journal of Electrochemical Science, 7(8) (2012) 7206 - 7224.

[34] O. O. Okoturo, T. J. Van der Noot, Temperature dependence of viscosity for room temperature ionic liquids, Journal of Electroanalytical Chemistry, 568(1-2) (2004) 167 - 181

[35] M. A. Kareem, F. S. Mjalli, M. A. Hashim, I. M. AINashef, Liquid-liquid equilibria for the ternary system (phosphonium based deep eutectic solvent-benzene-hexane) at different temperatures: a new solvent introduced, Fluid Phase Equilibria, 314 (2012) 52 - 59.

[36] A. M. Popescu, The viscosity of molten alkali fluorides, Revue Roumaine De Chimie, 44(8) (1999) 765-770.

[37] G. J. Janz, R. P. T. Tomkins, C. B. Allen, J. R. Downey, G. L. Gardner, U. Krebs, S. K. Singer, Molten salts: Volume 4, part 2, chlorides and mixtures-electrical conductance, density, viscosity, and surface tension data, Journal of Physical and Chemical Reference Data, 4(4) (1975) 871 $-1178$.

[38] P. Bonhöte, A. P. Dias, N. Papageorgiou, K. Kalyanasundaram, M. Grätzel, Hydrophobic, highly conductive ambient-temperature molten salts, Inorganic Chemistry, 35(5) (1996) 1168 - 1178.

[39] J. O'M. Bockris, A. K N. Reddy, Modern electrochemistry, Plenum Press, NY, Vol. 1, 1970, p. 547.

[40] S. Zhang, N. Sun, X. He, X. Lu, X. Zhang, Physical properties of ionic liquids: Database and evaluation, Journal of Physical and Chemical Reference Data, 35(4) (2006) 1475 - 1517.

[41] H. Eyring, M. S. John, Significant liquid structures, Wiley, New York, 1969.

[42] R. J. Martins, M. J. E. de M. Cardoso, O. E. Barcia, Excess Gibbs free energy model for calculating the viscosity of binary liquid mixtures, Industrial \& Engineering Chemistry Research, 39(3) (2000) 849 - 854.

[43] C. A. Angell, Molten salts and ionic liquids: Never the twain? in: M. Gaune-Escard, K. R. Seddon (Eds.), John Wiley \& Sons, Inc., USA, 2010, p. 1-24.

[44] W. Xu, E. I. Cooper, C. A. Angell, Ionic liquids: Ion mobilities, glass temperatures, and fragilities, The Journal of Physical Chemistry B, 107(25) (2003) 6170 - 6178.

[45] K. Kubota, K. Tamaki, T. Nohira, T. Goto, R. Hagiwara, Electrochemical properties of alkali bis(trifluoromethylsulfonyl)amides and their eutectic mixtures, Electrochimica Acta, 55(3) (2010) 1113-1119.

[46] H. Ohno (Ed.), Electrochemical aspects of ionic liquids, 2nd ed., John Wiley \& Sons, Inc., Hoboken, NJ, USA, 2011, DOI: 10.1002/9781118003350.ch2

[47] M. Yoshizawa, W. Xu, C. A. Angell, lonic liquids by proton transfer: vapor pressure, conductivity, and the relevance of $\Delta \mathrm{pKa}$ from aqueous solutions, Journal of the American Chemical Society, 125(50) (2003) 15411 - 15419.

[48] T.-Y. Wu, S.-G. Su, Y.-C. Lin, H. P. Wang, M.-W. Lin, S.T. Gung, I.-W. Sun, Electrochemical and physicochemical properties of cyclic amine-based Brønsted acidic ionic liquids, Electrochimica Acta, 56(2) (2010) 853 - 862. 


\section{Izvod \\ EUTEKTIČKI RASTVARAČI NA BAZI LIMUNSKE KISELINE: FIZIČKE OSOBINE I NJIHOVA UPOTREBA KAO KOSOLVENATA U ETANOLIZI OLEINSKE KISELINE KATALIZOVANE SUMPORNOM KISELINOM}

Dragan Z. Troter ${ }^{1}$, Milica Z. Zlatković ${ }^{1}$, Dušica R. Đokić-Stojanović Sandra S. Konstantinović ${ }^{1}$, Zoran B. Todorović ${ }^{1}$

1 Tehnološki fakultet, Univerzitet u Nišu, Leskovac, Serbia

2 Zdravlje Actavis, Leskovac, Serbia

Eutektički rastvarači (DESs) su analozi „zelenih“ jonskih tečnosti (IL), i njihove mnoge povoljne osobine ih čine interesantnim za naučnu zajednicu. U ovom radu dva nova eutektička rastvarača na bazi limunske kiseline sa monosaharidima D-glukozom ili D-fruktozom (u molarnom odnosu 1:1) su pripremljene i okarakterisane. $\mathrm{Na}$ atmosferskom pritisku gustina, dinamički viskozitet i električna provodljivost ovih eutektičkih rastvarača su izmereni i analizirani kao funkcija temperature u praktičnom temperaturnom opsegu od 293.15-363.15 K.

Arenijusova teorija je primenjena za razumevanje fenomena transporta u ovim eutektičkim rastvaračima. Korišćenjem eksperimentalnih podataka, izračunata su neka važna svojstva, kao što su, molekularna zapremina, energija rešetke, toplotni kapacitet, molarna Gibsova energija, entalpija i entropija aktivacije viskoznog protoka za sintetisane eutektičke rastvarače. Frakciono Valdenovo pravilo je korišćeno za određivanje odnosa između molarne provodljivosti i viskoziteta, čime se pokazalo odlično linearno ponašanje.

Konačno, ovi eutektički rastvarači su testirani kao kosolventi u etanolizi oleinske kiseline. Sintetisani eutektički rastvarači poseduju mnoge poželjne osobine, poput niskog pritiska pare, nezapaljivost, biorazgradivost i mogu se dobiti iz raspoloživih obnovljivih izvora. Ovi eutektički rastvarači pokazuju potencijal za korišćenje u nekim industrijskim procesima, kao što su obrada i separacija hranljivih sastojaka, farmaceutski procesi i kao medijumi za hemijske reakcije.
(ORIGINALNI NAUČNI RAD)

UDK 66.061.18:547.477:577.114

Ključne reči: eutektički rastvarač, limunska kiselina, glukoza, fruktoza, fizičke osobine, etanoliza 